Crop Breeding and Applied Biotechnology 12: 164-170, 2012

Brazilian Society of Plant Breeding. Printed in Brazil

ARTICLE

\title{
Tagging microsatellite marker to a blast resistance gene in the irrigated rice
} cultivar Cica-8

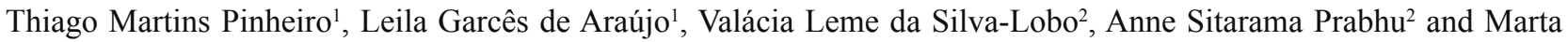
Cristina de Filippi*2

Received 14 October 2011

Accepted 20 March 2012

\begin{abstract}
The rice cultivar Cica-8 exhibit differential reaction to several pathotypes of Magnaporthe oryzae. The objective of the present investigation was to determine the number of alleles involved in the expression of resistance to leafblast and identify microsatellite markers linked to these alleles. A cross between cultivar Metica-1 and Cica-8 susceptible and resistant, respectively, to pathotype IB-1 (Py1049) was made to obtain $F_{1}, F_{2}, B C_{1: 1}$ and $B C_{1: 2}$ progenies. Greenhouse tests for leaf blast reaction showed that resistance is controlled by a monogenic dominant gene. For testing microsatellite markers, DNA of both resistant and susceptible parents and $F_{1}$ and $F_{2}$ populations was extracted. As expected for single dominant gene the $F_{2}$ populations segregated at a ratio of 3:1. Of the 11 microsatellite markers tested, one marker RM 7102 was found to be closely linked to the resistant allele at a distance of 2.7 cM, in the cultivar Cica-8 to pathotype IB-1.
\end{abstract}

Key words: Oryza sativa, Pyricularia oryzae, DNA markers, marker assisted selection.

\section{INTRODUCTION}

Rice blast caused by Magnaporthe oryzae B. Couch [anamorph - Pyricularia oryzae Cavra] ranks first in order of economic importance in Brazil. The grain yield losses caused by rice blast are worldwide. In China, over 3.8 million hectares were affected in 1993 causing losses of approximately 1.1 million tons, whereas in Japan the yield losses were estimated to vary between 20 to 100\% (Khush and Jena 2009). In Brazil, the losses were reported to be as high as $100 \%$ in susceptible upland rice cultivars under upland conditions (Prabhu et al. 2009). Even though there are no reliable estimates of losses in irrigated rice, they are considered significant, because the farmers resort to intensive fungicide spraying to control blast. Breeding for blast resistance is the most economic means of reducing losses in yield as well as in grain quality.

Identification of resistance genes with molecular markers is the basic requisite for marker-assisted selection (MAS) in resistance breeding. Several DNA markers closely linked to agronomic traits have been developed for indirect selection for traits of interest in segregating populations (Caixeta et al. 2009). The indirect selection is highly effective due to the absence of confounding effect of environment and also pyramiding of genes for disease resistance, which is difficult through the use of conventional plant breeding methods (Gupta and Varshney 2000). The availability of different molecular markers permits characterization of genes of interest. Nearly 60 blast resistance genes have been identified following conventional genetic analysis of resistant donors using specific pathotypes and molecular analysis techniques (Khush and Jena 2009). In rice, molecular markers have been successfully used to pyramid bacterial blight resistance genes into isogenic lines (Huang et al. 1997) and three blast resistance genes in a single genotype (Hittalmani et al. 2000).

Among the PCR-based markers $\left(\mathrm{RAPD}_{\mathrm{S}}, \mathrm{SCAR}_{\mathrm{S}}, \mathrm{CAPS}\right.$, STS, STMS, AFLP $_{S}$ etc.) microsatellites have attracted attention, because they are hypervariable, abundant and well distributed throughout the rice genome and are easily available through the published linkage map or in public data base and permit differentiation of homo and heterozygote individuals (McCouch et al. 2002, Caixeta et al. 2009). The speed, reliability and cost effectiveness make microsetellite analysis on acrylamide gel an attractive tool for MAS in blast resistance breeding (Fuentes et al. 2008).

\footnotetext{
1 Universidade Federal de Goiás, Escola de Agronomia e Engenharia de Alimentos, Goiânia, GO, Brazil

2 Embrapa Arroz e Feijão, Rodovia GO-462, km 12, Zona Rural, 75.375-000, Santo Antônio de Goiás, GO, Brazil. *E-mail: cristina@cnpaf.embrapa.br
} 
TM Pinheiro et al.

Korean cultivar Suweon 365 carries three major resistance genes, $P i 18, P i 21(\mathrm{t})$, and $P i 22(\mathrm{t})$, against Korean isolates KI313 , KJ-101, and KJ-201, respectively, using microsatellite markers in an $\mathrm{F}_{2}$ population derived from a cross of cultivars Suweon and Chucheongbyeo (Ahn et al. 2000). A resistance gene, $\mathrm{Pi}$-CO39, corresponding to a virulence gene Avr 1-CO39, was identified in cultivar CO39 through linkage analysis in a $\mathrm{F}_{2}$ population from a cross between cultivars $\mathrm{CO} 39$ and 51583 with microsatellite and RFLP markers (Chauhan et al. 2002). Microsatellite markers (SSR) were used for mapping the gene $\mathrm{Pik}^{\mathrm{h}}$, that confer resistance to blast races in Himalyan region of north east India (Sharma et al. 2005). In Colombia, of the 24 microsatellite sequences tested, six showed polymorphism and two markers RM1233 and RM224 were linked to the gene $P i-1(\mathrm{t})$ in the same position $(0.0 \mathrm{cM})$. Furthermore, microsatellite analysis of advanced rice breeding lines with genetic background showed that all known sources of blast resistance carry the specific $P i-1(\mathrm{t})$ allele (Fuentes et al. 2008).

The cultivar Cica-8 shows resistance to several Brazilian blast fungus races. To effectively use its resistance gene in a rice breeding program, it is important to tag the resistance gene or genes present in this cultivar with molecular markers. The present investigation was undertaken to determine the number of alleles in the expression of rice blast resistance and identify microsetellite markers linked to these genes.

\section{MATERIAL AND METHODS}

\section{Plant material for inheritance studies}

The populations of $\mathrm{F}_{1}, \mathrm{~F}_{2}$ and $\mathrm{BC}$ were obtained from a cross between irrigated rice cultivar Metica- 1 and cultivar Cica-8, susceptible and resistant, respectively, to pathotype IB-1, in Embrapa Rice and Beans Research Center, Santo Antônio de Goiás, GO. A part of $\mathrm{F}_{1}$ seed (600) was used for backcross with susceptible parent Metica-1 $\left(\mathrm{BC}_{1: 1}\right)$ and with resistant parent Cica-8 $\left(\mathrm{BC}_{1: 2}\right)$ to obtain 400 seeds of each backcross and the remaining $\mathrm{F}_{1}$ plants were self-pollinated to generate $1400 \mathrm{~F}_{2}$ progeny seeds.

\section{Inoculation and evaluation}

The test material was planted in plastic trays $(30 \mathrm{~cm} \mathrm{x}$ $15 \mathrm{~cm} \times 10 \mathrm{~cm}$ ) containing $5 \mathrm{~kg}$ of soil fertilized with $5 \mathrm{~g}$ of NPK 5-30-15, $2 \mathrm{~g}$ of ammonium sulfate and $1 \mathrm{~g}$ of zinc sulfate. The seed was sown in eight $10 \mathrm{~cm}$ along rows at the rate of 15 seeds per row. The plants after germination were thinned to maintain 10 plants per row. Thirty plants of each parent Metica-1 and Cica-8, 20 plants of $\mathrm{F}_{1}, 200$ plants of $\mathrm{F}_{2}, 100$ plants of each backcross were planted in 12 trays.

The monosporic isolate Py 1049 of M. oryzae originated from cultivar Metica-1 was used for inoculation and evaluation of leaf blast reaction. The isolate was identified as pathotype IB-1 based on previous inoculation testes on eight standard international differentials. Initially the pure culture was multiplied in Petri plates containing culture medium PDA (potato-dextrose-agar). For sporulation, mycelial discs were grown on oat meal agar medium in plates and incubated at $27^{\circ} \mathrm{C}$, for 10 days under continuous fluorescent day light. The aerial mycelium was scrapped with a sterilized glass rod under asceptic conditions. The plates were later kept under fluorescent day light for 48 hours with lids open but covered with sterilized cheese cloth. Inoculum was prepared by flooding culture plates with distilled water and conidia were dislodged with a paint brush. The conidial suspension along with the scrapped mycelium was filtered through double layer of cheese cloth. The final conidial suspension was adjusted to $3 \times 10^{5}$ conida $\mathrm{mL}^{-1}$ using haemocytometer.

Twenty one day-old plants with three fully opened leaves were inoculated with spores suspension on the leaves, until run-off, using a Devilbis automizer connected to an air compressor. The inoculated plants were kept in moist chamber for $24 \mathrm{~h}$ at temperatures ranging from $19^{\circ} \mathrm{C}$ to $21^{\circ} \mathrm{C}$. Subsequently they were transferred to greenhouse benches where the mean temperature was $28^{\circ} \mathrm{C}$ and humidity $>80 \%$.

The plants were evaluated after seven days for leaf blast reaction using a 0-9 scale according to IRRI (1996). The disease ratings 5, 7 and 9 were considered susceptible or compatible and 0,1 and 3 resistant or incompatible. The frequency of resistant and susceptible plants in $\mathrm{F}_{2}$ and backcross progeny was assessed and chi-square $\left(x^{2}\right)$ analysis was done for goodness of fit (Strickberger 1971).

\section{Identification of microsetellite markers linked to resistance gene}

The rice leaves were macerated in liquid nitrogen and DNA extracted according to Doyle and Doyle (1987). The DNA concentration was adjusted to $10 \mathrm{ng} \mu \mathrm{L}^{-1}$ and has been estimated visually utilizing the standard DNA lambda at concentrations of $50 \mathrm{ng} \mu \mathrm{L}^{-1}, 100 \mathrm{ng} \mu \mathrm{L}^{-1}$ and $200 \mathrm{ng} \mu \mathrm{L}^{-1}$. The microsatellites utilized are shown in Table 1.

Table 1. Relation of selected microsatellite primers

\begin{tabular}{lccc}
\hline Marker & $\begin{array}{c}\text { Expected size } \\
\text { (bp) }\end{array}$ & Gene & Reference \\
\hline 9871.T7E2b & 642 & Pi5 & Suh et al. (2009) \\
\hline yca72 & 635 & Pia & Suh et al. (2009) \\
\hline RM224 & 122 & Pi1 & Jia and Moldenhauer (2010) \\
\hline OSR32 & 247 & Pita & Li et al. (2008) \\
\hline RM7102 & 170 & Pi41 & Yang et al. (2009) \\
\hline RM6836 & 178 & Piz & Fjellstrom et al. (2006) \\
\hline pBA14 & 480 & Pi9 & Liu et al. (2002) \\
\hline RM144 & 254 & Piks & Jia and Moldenhauer (2010) \\
\hline RM28130 & 176 & Pi40 & Yang et al. (2009) \\
\hline RM1261 & 167 & Pi41 & Yang et al. (2009) \\
\hline JJ817 & 1450 & Pi5 & Suh et al. (2009) \\
\hline
\end{tabular}


Each polymerase reaction was conducted in a final volume of $40 \mu \mathrm{L}$ containing genomic DNA, buffer $(100 \mathrm{mM}$ Tris-HCl, $\mathrm{pH} 8,8$ and $500 \mathrm{mM} \mathrm{KCl}), \mathrm{MgCl}_{2}(25 \mathrm{mM}), \mathrm{dNTP}(2 \mathrm{mM}$ of each dATP, dGTP, dCTP e dTTP), marker (forward and reverse) and Taq DNA polymerase. The enzymatic amplification was performed in a thermocycler (ESCO Swift MaxPro) with amplification program specified for each marker. For microsatellite markers utilized in this study the reaction was processed as shown in Table 2.

Table 2. Procedure for each microsetellite marker utilized

\begin{tabular}{|c|c|}
\hline Marker & Procedure \\
\hline 9871.T7E2b & $\begin{array}{l}4 \text { minutes at } 95^{\circ} \mathrm{C}, 35 \text { cycles for } 30 \text { seconds at } 95 \\
{ }^{\circ} \mathrm{C}, 30 \text { seconds at } 55^{\circ} \mathrm{C} \text { and } 1 \text { minute at } 72{ }^{\circ} \mathrm{C} \text { and } 10 \\
\text { minutes at } 72{ }^{\circ} \mathrm{C}\end{array}$ \\
\hline yca72 & $\begin{array}{l}4 \text { minutes at } 95^{\circ} \mathrm{C}, 35 \text { cycles for } 30 \text { seconds at } 95 \\
{ }^{\circ} \mathrm{C}, 30 \text { seconds at } 55^{\circ} \mathrm{C} \text { and } 1 \text { minute at } 72^{\circ} \mathrm{C} \text { and } 10 \\
\text { minutes at } 72{ }^{\circ} \mathrm{C}\end{array}$ \\
\hline RM224 & $\begin{array}{l}1 \text { minute at } 94{ }^{\circ} \mathrm{C}, 40 \text { cycles for } 30 \text { seconds at } 94^{\circ} \mathrm{C} \text {, } \\
30 \text { seconds at } 55^{\circ} \mathrm{C} \text { and } 30 \text { seconds at } 72{ }^{\circ} \mathrm{C} \text { and } 10 \\
\text { minute at } 72{ }^{\circ} \mathrm{C}\end{array}$ \\
\hline OSR32 & $\begin{array}{l}5 \text { minutes at } 94^{\circ} \mathrm{C}, 35 \text { cycles for } 1 \text { minute at } 94{ }^{\circ} \mathrm{C} \text {, } \\
50 \text { seconds at } 55^{\circ} \mathrm{C} \text { and } 1 \text { minute at } 72^{\circ} \mathrm{C} \text { and } 5 \\
\text { minute at } 72{ }^{\circ} \mathrm{C}\end{array}$ \\
\hline RM7102 & $\begin{array}{l}3 \text { minutes at } 95^{\circ} \mathrm{C}, 29 \text { cycles for } 30 \text { seconds at } 95^{\circ} \mathrm{C} \text {, } \\
30 \text { seconds at } 55^{\circ} \mathrm{C} \text { and } 30 \text { seconds at } 72^{\circ} \mathrm{C} \text { and } 7 \\
\text { minute at } 72^{\circ} \mathrm{C}\end{array}$ \\
\hline RM6836 & $\begin{array}{l}3 \text { minutes at } 95^{\circ} \mathrm{C}, 35 \text { cycles for } 30 \text { seconds at } 95 \\
{ }^{\circ} \mathrm{C}, 30 \text { seconds at } 55^{\circ} \mathrm{C} \text { and } 1 \text { minute at } 72{ }^{\circ} \mathrm{C} \text { and } 10 \\
\text { minute at } 722^{\circ} \mathrm{C}\end{array}$ \\
\hline pBA14 & $\begin{array}{l}4 \text { minutes at } 94^{\circ} \mathrm{C}, 35 \text { cycles for } 45 \text { seconds at } 94 \\
{ }^{\circ} \mathrm{C}, 45 \text { seconds at } 55^{\circ} \mathrm{C} \text { and } 1 \text { minute at } 72{ }^{\circ} \mathrm{C} \text { and } 5 \\
\text { minutes at } 72{ }^{\circ} \mathrm{C}\end{array}$ \\
\hline RM144 & $\begin{array}{l}5 \text { minutes at } 94{ }^{\circ} \mathrm{C}, 35 \text { cycles for } 1 \text { minute at } 94{ }^{\circ} \mathrm{C}, 1 \\
\text { minute at } 55^{\circ} \mathrm{C} \text { and } 2 \text { minute at } 72{ }^{\circ} \mathrm{C} \text { and } 7 \text { minute } \\
\text { at } 72{ }^{\circ} \mathrm{C}\end{array}$ \\
\hline RM28130 & $\begin{array}{l}3 \text { minutes at } 94{ }^{\circ} \mathrm{C}, 35 \text { cycles for } 30 \text { seconds at } 94 \\
{ }^{\circ} \mathrm{C}, 30 \text { seconds at } 55^{\circ} \mathrm{C} \text { and } 1 \text { minute at } 72^{\circ} \mathrm{C} \text { and } 7 \\
\text { minute at } 72{ }^{\circ} \mathrm{C}\end{array}$ \\
\hline RM1261 & $\begin{array}{l}5 \text { minutes at } 94^{\circ} \mathrm{C}, 35 \text { cycles for } 1 \text { minute at } 94^{\circ} \mathrm{C} \text {, } \\
1 \text { minute at } 55^{\circ} \mathrm{Ce} 2 \text { minute at } 72^{\circ} \mathrm{C} \text { and } 7 \text { minute } \\
\text { at } 72^{\circ} \mathrm{C}\end{array}$ \\
\hline JJ817 & $\begin{array}{l}4 \text { minutes at } 95{ }^{\circ} \mathrm{C}, 35 \text { cycles for } 30 \text { seconds at } 95 \\
{ }^{\circ} \mathrm{C}, 30 \text { seconds at } 55^{\circ} \mathrm{C} \text { and } 1 \text { minute at } 72^{\circ} \mathrm{C} \text { and } 10 \\
\text { minutes at } 72^{\circ} \mathrm{C}\end{array}$ \\
\hline
\end{tabular}

The amplification products were separated in polyacrylamide gel $(6 \%)$. The images were obtained utilizing scanner HP Scanjet 3770. For the identification of markers linked to resistance genes to isolate Py 1049 in the test populations, evaluation and selection was done in the following three steps: In the first step 11 microsatellite primers (Table 1) were tested and only those that were capable of detecting polymorphism among parents were selected for second step. In the second step, only the primers capable of amplifying the same standard polymorphism in parents and bulks were selected for third step. The bulks of $F_{1}, F_{2}$ resistant and $F_{2}$ susceptible, each contained DNA (10 ng) of seven individuals of each population. In the final step, the above selected primers were utilized for amplification of reactions that contained DNA with each individual component of bulks previously described. Each primer selected participated in the following reaction amplification: a) resistant parent (1 reaction); b) susceptible parent (1 reaction); c) seven individuals of $\mathrm{F}_{1}$ population (seven reactions); d) seven individuals of resistant $\mathrm{F}_{2}$ and; e) seven individuals of susceptible $\mathrm{F}_{2}$ (seven reactions).

\section{Analysis}

For estimating the distance between microsatellite marker and resistance gene, 200 individual $\mathrm{F}_{2}$ populations were evaluated phenotypically and genotypically. The distance was estimated utilizing the software MAP-MAKER III with one minimum lod score of 3.0 and Kosambi function of mapping (Lander et al. 1987).

\section{RESULTS AND DISCUSSION}

Genetic analysis of resistance of the cultivar Cica- 8 was conducted by inoculating $\mathrm{F}_{1}, \mathrm{~F}_{2}, \mathrm{BC}_{1}$ and $\mathrm{BC}_{2}$ populations obtained from a cross between cultivars Metica-1 and Cica- 8 with the isolate Py 1049 under greenhouse conditions. The observed and expected ratios are presented in Table 3. The $\mathrm{F}_{1}$ plants showed resistant reaction whereas $F_{2}$ population segregated at a ratio of 3:1 resistant and susceptible plants indicating that the resistance to pathotype IB-1 in the cultivar Cica-8 is dominant and monogenic. These results were confirmed by the expected segregation ratio of 1:1 resistant and susceptible plants of backcross population to susceptible parent $\left(\mathrm{BC}_{1: 1}\right)$ and resistant reaction of plants of backcross $\left(\mathrm{BC}_{1: 2}\right)$ with resistant parent.

Table 3. Segregation of $\mathrm{F}_{1}, \mathrm{~F}_{2}, \mathrm{BC}_{1: 1}, \mathrm{BC}_{1: 2}$ populations of a cross between Metica-1 and Cica-8, susceptible and resistant, respectively, to pathotype IB-1 of Magnaporthe oryzae

\begin{tabular}{|c|c|c|c|c|c|c|}
\hline \multirow{2}{*}{$\begin{array}{l}\text { Parents/ } \\
\text { generation }\end{array}$} & \multirow{2}{*}{$\begin{array}{l}\text { No. of } \\
\text { plants }\end{array}$} & \multicolumn{2}{|c|}{$\begin{array}{c}\text { Observed } \\
\text { data }\end{array}$} & \multirow{2}{*}{$\begin{array}{c}\text { Expected } \\
\text { ratio }^{3}\end{array}$} & \multirow{2}{*}{$\chi^{2}$} & \multirow[t]{2}{*}{$\mathbf{F}$} \\
\hline & & $\mathrm{R}$ & $\mathrm{S}$ & & & \\
\hline Metica-1 & 30 & 0 & 30 & - & & \\
\hline Cica-8 & 30 & 30 & 0 & - & & \\
\hline $\mathrm{F}_{1}$ & 20 & 20 & 0 & - & & \\
\hline $\mathrm{F}_{2}$ & 200 & 137 & 63 & $3: 1$ & 4.167 & $0.041227^{*}$ \\
\hline $\mathrm{BC}_{1: 1}{ }^{1}$ & 82 & 31 & 51 & $1: 1$ & 4.402 & $0.035888 *$ \\
\hline $\mathrm{BC}_{1: 2}^{2}$ & 100 & 79 & 21 & $1: 0$ & 4.203 & $0.040364 *$ \\
\hline
\end{tabular}

${ }^{1}$ Backcross to susceptible parent Metica-1

${ }^{2}$ Backcross to resistant parent Cica- 8

${ }^{3}$ Expected ratio resistant to susceptible

${ }^{4 *}$ Significant at $5 \%$ probability

Based on studies on genetic resistance, in five improved and four traditional cultivars using three rice blast isolates, Yu et al (1986) showed that resistance is controlled by one or two dominant genes. The analysis of isogenic lines with single resistance genes showed that the resistance is controlled by independent dominant genes (Mackill and Bonman 1992). 
In Brazil, the inheritance studies conducted with 12 different crosses, Filippi and Prabhu (1996) observed that the resistance to the predominant races IB-1 and IB-9 was dominant and controlled by one or three genes. Nunes et al. (2007) showed that the resistance in irrigated rice cultivars Taim and BRS Firmeza is controlled by one dominant gene. The resistance in Cica- 8 is controlled by a pair of dominant alleles and segregated independently confirming the majority of the earlier studies on inheritance of resistance conducted in Brazil and elsewhere.

Of all 11 markers tested, four markers, RM224, RM7102, RM1261 and yca72 were polymorphic and showed amplification differentiating the resistant and susceptible parent (Figure 1). These four polymorphic markers were tested in

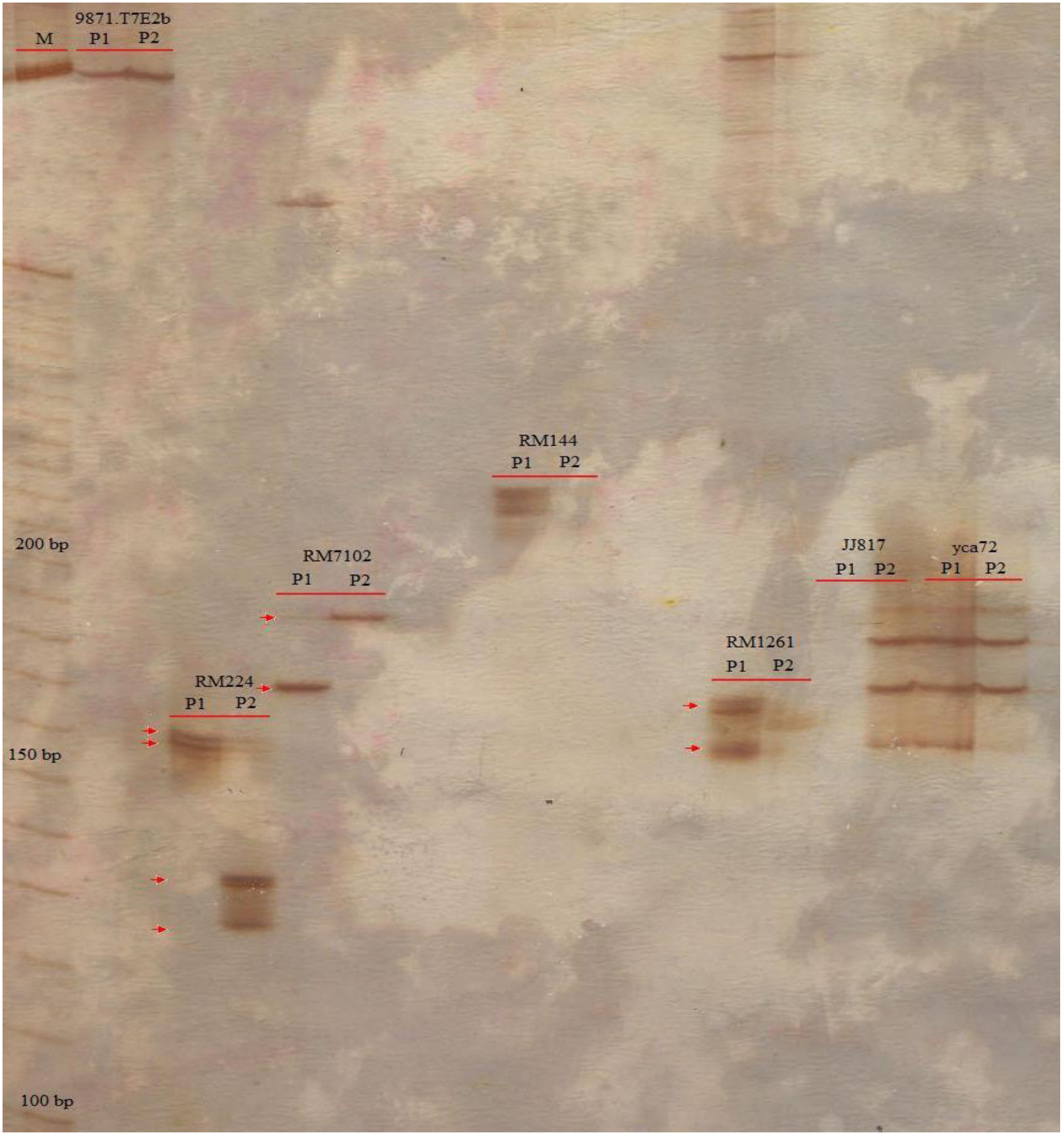

Figure 1. Amplification pattern observed in denatured polyacrylamide gel (6\%) for all primers tested. From left to right: M: Ladder 10 bp; P1: susceptible parent (Metica-1) to isolate Py 1049 and P2: resistance donor parent (Cica-8) to the isolate Py 1049. 
bulk populations of segregating $\mathrm{F}_{2}$ resistant, $\mathrm{F}_{2}$ susceptible and $\mathrm{F}$ plants (Figure 2). It was possible to detect the same amplification of bulks, observed in parents, in three markers (RM224, RM1261 and RM7102). Only one marker RM7102 showed standard amplification and expected polymorphism or in other words the amplification observed in resistant parent was repeated in resistant $\mathrm{F}_{1}$ and $\mathrm{F}_{2}$ bulks. The polymorphic bands with 170 and 190 base pairs were tested in seven individual components of each bulk.

It was possible to observe in individuals $\mathrm{F}_{1-1}$ to $\mathrm{F}_{1-7}$, tested with marker RM7102, the presence of two bands one on the top similar to that observed in parent Cica-8, resistant to isolate Py 1049 , with 190 base pairs (pb), and one on the botton with $170 \mathrm{pb}$, similar to that observed in susceptible cultivar Metica-1. This pattern of amplification is in accord with its heterozygote condition (Figure 2). The same amplification pattern for microsatellite marker RM7102 and individual resistant $\mathrm{F}_{2}$ population $\left(\mathrm{F}_{2} \mathrm{R}_{1}\right.$ to $\left.\mathrm{F}_{2} \mathrm{R}_{7}\right)$ was obtained. All showed similar bands indicating that these individuals are also heterozygotes. The individual susceptible $\mathrm{F}_{2}$ plants showed only inferior band (170 pb), similar to the susceptible parent Metica-1. This amplification pattern suggest that the top band $(190 \mathrm{pb})$ is associated with resistance to isolate Py 1049, observed in this population, and the bottom band is possibly a recessive allele, associated with the susceptibility inherited of the parent Metica-1 (Figure 2). It was verified that this marker is linked to the resistance gene at a distance of $2.7 \mathrm{cM}$ (Figure 3 ).

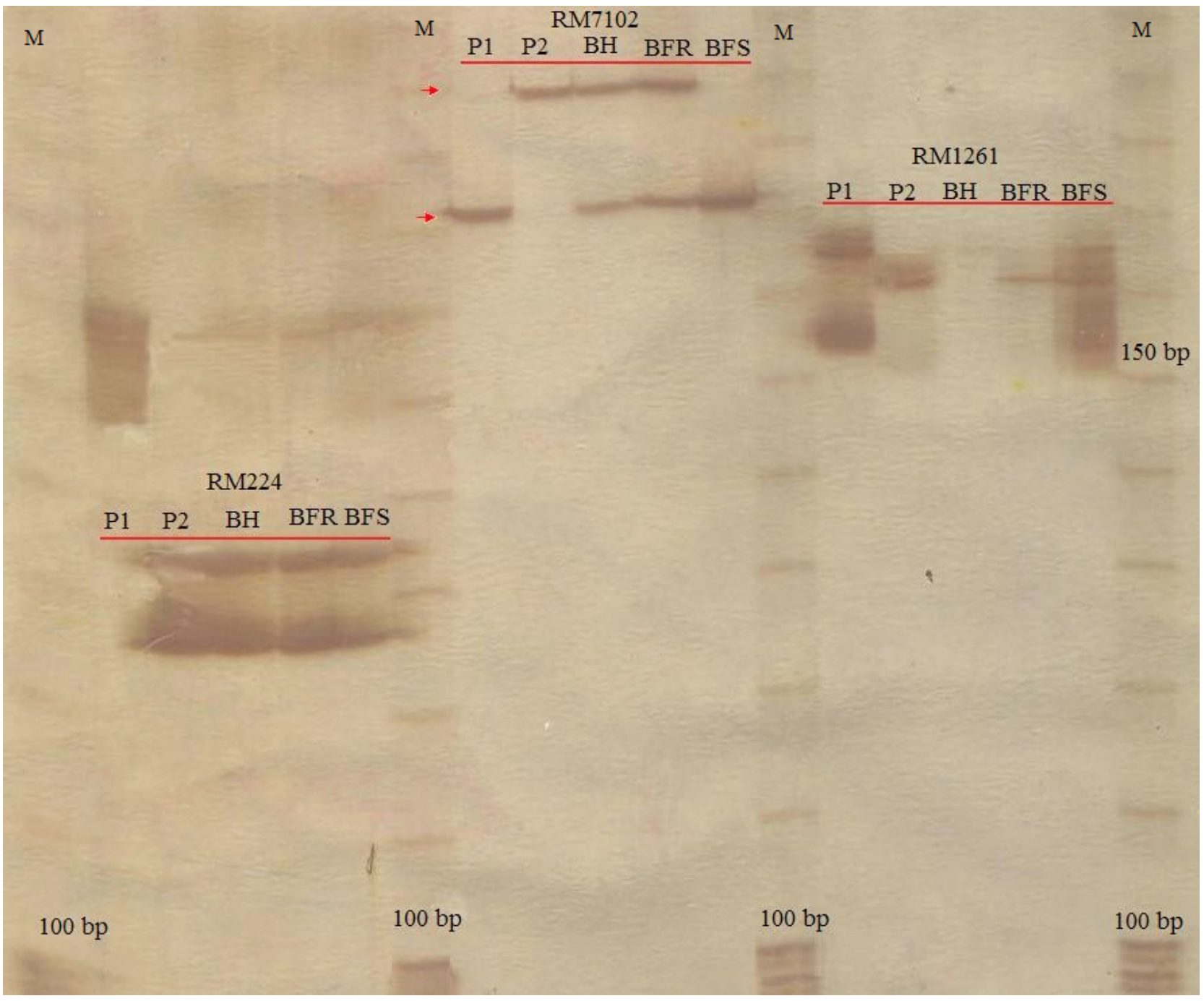

Figure 2. Amplification pattern observed in denatured polyacrylamide gel (6\%) for primers RM224, RM7102, RM1261 and yca72 (no amplification) in bulks $\mathrm{F}_{1}$ and $\mathrm{F}_{2}$ resistant and susceptible populations. From left to right: M: Ladder $10 \mathrm{bp}$; P1: susceptible parent (Metica-1) to isolate Py 1049; P2: resistance donor parent (Cica-8) to the isolate Py 1049; BH: $\mathrm{F}_{1}$ bulk population; BFR: $\mathrm{F}_{2}$ resistant bulk; BFS: $\mathrm{F}_{2}$ susceptible bulk. 


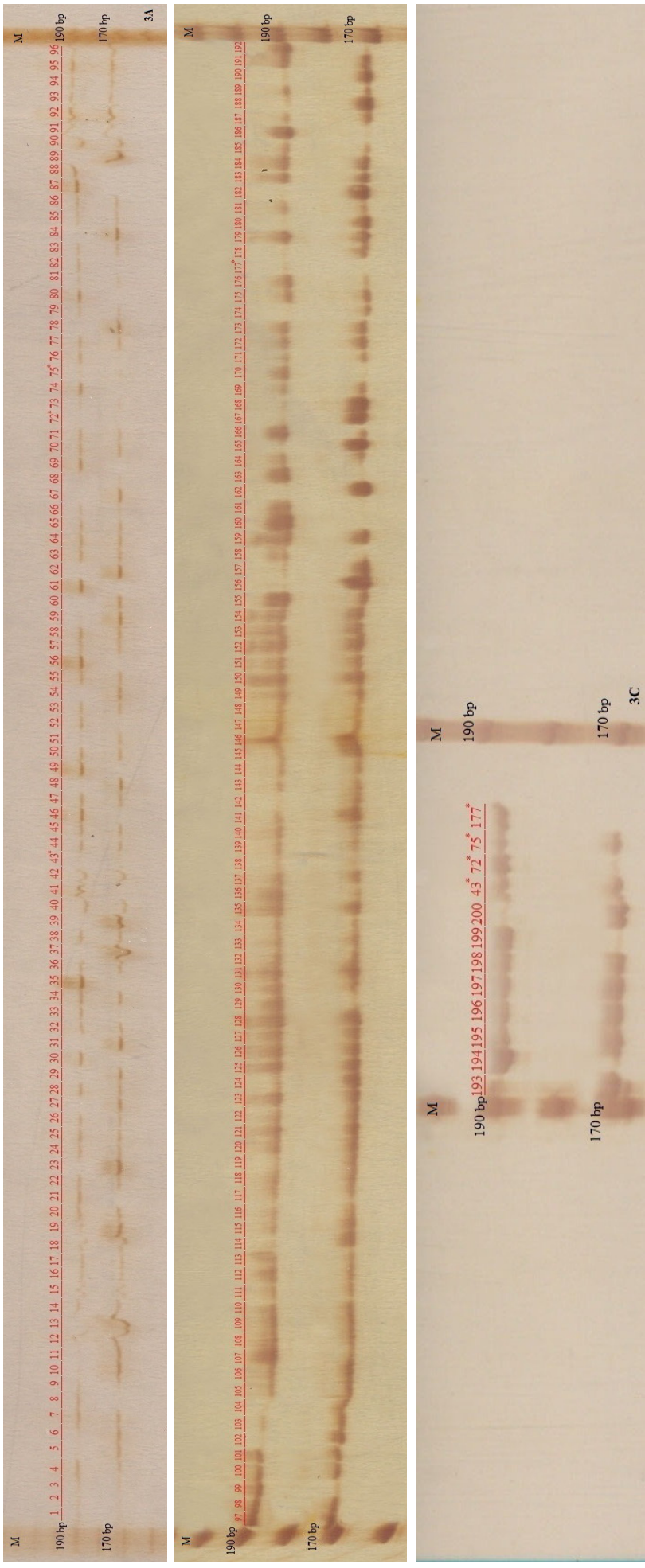

Figure 3. Amplification pattern observed in denatured polyacrylamide gel $(6 \%)$ in individual $\mathrm{F}_{1}, \mathrm{~F}_{2}$ resistant and $\mathrm{F}_{2}$ susceptible populations by marker RM7102. From left to right: M: Ladder $10 \mathrm{bp}$; 3A, 3B and 3C: numbers 1 to 200 of $\mathrm{F}_{2}$ resistant and susceptible plants.
Yang et al. (2009), working on identification and mapping of gene Pi41, utilized resistant cultivar 93-11 and susceptible cultivar Nipponbare, and $\mathrm{F}_{2}$ population derived from this cross, to challenge with two blast isolates (CHL724 e CHL743). They showed different responses to resistance and susceptibility in these parents. For this study, they utilized 180 microsatellite markers and obtained seven markers linked to the gene Pi4l, RM7102 being one of them.

The markers RM144, RM224 and yca72 were related to resistance genes Pi- $k^{s}, P i 1$ and Pia, respectively (Suh et al. 2009, Jia and Moldenhauer 2010), indicating that these genes are not associated with resistance in cultivars Metica-1 and Cica-8. The marker RM1261 (Yang et al. 2009) was polymorphic to parents but not to $\mathrm{F}_{1}, \mathrm{~F}_{2} \mathrm{R}$ and $\mathrm{F}_{2} \mathrm{~S}$ bulks. This marker is related to gene Pi4l, but did not show association to resistance allele of the cultivar Cica-8. It can be inferred that Pi41 and the allele identified in Cica- 8 are similar but show some differences among them.

Bryan et al. (2000) reported that change in single aminoacid differentiate resistant and susceptible alleles in gene $P i$ - $t a$, because they modify the proteins that will be codified by gene. According to Jia et al. (2000) the substitution of single aminoacid in leucine-rich domain of gene Pi-ta or in gene AVR-Pita ${ }_{176}$ results in loss of resistance in plant. These results demonstrated that even with little alterations in aminoacids of genes the resistance and/or avirulence are capable of inducing variability and loss of resistance. The gene Pita is localized in a stable region close to centromere (Zhou et al. 2007). This gene codifies cytoplasmic protein NBS-LRR, following the mold of majority of cloned genes. The same is capable of producing 12 different proteins, which are effective against 10 pathotypes. On the other hand, the avirulence allele AVR-Pita is localized in one unstable telomeric region of the chromosome and the protein has been shown to be frequently altered under field conditions. The high specificity of pathotype IB- 1 to cultivar Cica- 8 has been reported (Araujo and Prabhu 2004) and resistance until today is highly stable. However, investigations concerning alteration of AVR gene frequency in a P. oryzae population have been done for many years around the world. But we are still looking for complementary strategies of disease management.

The microsatellite marker RM7102 which is tightly linked $(2.7 \mathrm{cM})$ to the blast resistance gene, to IB-1 pathotype, in cultivar Cica-8 in rice, showed accuracy of $98 \%$ in identifying the resistant plants in segregating populations and thus provide means to conduct marker assisted selection in a rice breeding program. This information is also useful for the strategies of pyramiding different major resistance genes and gene rotation, which are important components in integrated pest management.

\section{ACKNOWLEDGEMENTS}

The authors acknowledge the support received by Embrapa Rice and Bean, by granting equipment usage and CAPES, for financial support to the principal author. 


\title{
Marcadores microssatélites ligados a gene de resistência à brusone na cultivar de arroz irrigado Cica-8
}

\begin{abstract}
Resumo - A cultivar de arroz Cica-8 apresenta reação diferencial a vários patótipos de Magnaporthe oryzae. Este trabalho teve como objetivo determinar o número de alelos envolvidos na expressão de resistência do arroz à brusone e identificar marcadores microssatélites ligados a estes alelos. Foi realizado um cruzamento entre as cultivares Metica-1 e Cica-8, resistente e suscetivel, respectivamente, ao patotipo IB-1 (Py1049) para obtenção de progênies $F_{1}, F_{2}, R C_{1: 1}$ e $R C_{1: 2}$. Testes fenotípicos realizados em casa de vegetação para reação da brusone nas folhas mostrou que a resistência é controlada por um gene dominante. Para testar marcadores microssatélites selecionados, foram feitas extrações de DNA de cada genitor e das populações $F_{1}$ e $F_{2}$. Como esperado para um gene dominante, a população $F_{2}$ segregou em razão 3:1. Entre 11 marcadores microssatélites testados, um marcador, RM7102, encontrou-se ligado ao alelo de resistência à distancia de $2.7 \mathrm{cM}$ na cultivar Cica-8 para o patótipo IB-1.
\end{abstract}

Palavras-chave: Oryza sativa, Pyricularia oyzae, marcadores moleculares, seleção assistida.

\section{REFERENCES}

Ahn SN, Kim YK, Hong HC, Han SS, Kwon SJ, Choi HC, Moon HP and McCouch SR (2000) Molecular mapping of a new gene for resistance to rice blast (Pyricularia grisea Sacc.). Euphytica 116: 17-22.

Araujo LG and Prabhu AS (2004) Resistência parcial à brusone em somaclones da cultivar de Arroz CICA-8. Fitopatologia Brasileira 29: 394-398.

Bryan GT, Wu KS, Farrall L, Jia Y, Hershey H, McAdams SA, Faulk KN, Donaldson GK, Tarchini R and Valent B (2000) A single amino acid difference distinguishes resistant and susceptible alleles of the rice blast resistance gene Pi-ta. The Plant Cell 12: 2033-2045.

Caixeta ET, Oliveira ACB, Brito GG and Sakiyama NS (2009) Tipos de marcadores moleculares. In Borém A and Caixeta ET (eds.) Marcadores moleculares. Editora UFV, Viçosa, p. 11-93.

Chauhan RS, Farman ML, Zhang HB and Leong SA (2002) Genetic and physical mapping of a rice blast resistance locus, Pi-CO39(t), that corresponds to the avirulence gene AVR1-CO39 of Magnaporthe grisea. Molecular Genetics and Genomics 267: 603-612.

Doyle JJ and Doyle JL (1987) A rapid DNA isolation procedure for small quantities of fresh leaf tissue. Phytochemical Bulletin 19: 11-15.

Filippi MC and Prabhu AS (1996) Inheritance of blast resistance in rice to two Pyricularia grisea races IB-1 and IB-9. Brazilian Journal of Genetics 19: 599-604.

Fjellstrom R, Mcclung AM and Shank AR (2006) SSR markers closely linked to the Pi-z locus are useful for selection of blast resistance in a broad array of rice germplasm. Molecular Breeding 17: 149-157.

Fuentes JL, Correa-Victoria FJ, Escobar F, Prado G, Aricapa G, Duque $\mathrm{MC}$ and Thome J (2008) Identification of microsatellite markers linked to the blast resistance gene Pi-1(t) in rice. Euphytica 160: 295-304.

Gupta PK and Varshney RK (2000) The development and use of microsetellite markers for genetic analysis and plant breeding with emphasis on bread wheat. Euphytica 113: 163-185.

Hittalmani S, Parco A, Mew TV and Zeigler RS (2000) Fine mapping and DNA marker-assisted pyramiding of three major genes for blast resistance in rice. Theoretical and Applied Genetics 100: 1121-1128.

Huang N, Angeles ER, Domingo J, Magpantay G, Singh S, Zhang G, Kumaravadivel N, Bennett J and Khush GS (1997) Pyramiding of bacterial blight resistance genes in rice: marker-assisted selection using RFLP and PCR. Theoretical and Applied Genetics 95: 313-320.

IRRI - International Rice Research Institute (1996) Standard evaluation system for rice. IRRI, Manila, 52p.

Jia Y and Moldenhauer K (2010) Development of monogenic and digenic rice lines for blast resistance genes Pi-ta, $\mathrm{Pi}-\mathrm{k}^{\mathrm{h}} / \mathrm{Pi}-\mathrm{k}^{\mathrm{s}}$. Journal of Plant Registrations 4: 163-166.

Jia Y, McAdams AS, Bryan GT, Hershey HP and Valent B (2000) Direct interaction of resistance gene and avirulence gene products confers rice blast resistance. The European Molecular Biology Organization Journal 19: 4004-4014.

Khush GS and Jena KK (2009) Current status and future prospects for research on blast resistance in rice (Oryza sativa L.). In Wang GL and Valent B (eds.) Advances in genetics, genomics and control of rice blast. Springer Science, Netherlands, p. 1-10.

Lander ES, Green P, Abrahamson J, Barlow A, Daly M J, Lincoln SE and Newburg L (1987) Mapmaker: an interactive computer package for constructing primary genetic linkage maps of experimental and natural populations. Genomics 1: 174-181.

Li W, Lei C, Cheng Z, Jia Y, Huang D, Wang J, Wang J, Zhang X, Su N, Xiuping G, Zhai H and Wan J (2008) Identification of SSR markers for a broad-spectrum blast resistance gene Pi20(t) for marker-assisted breeding. Molecular Breeding 22: 141-149.

Mackill DJ and Bonman JM (1992) Inheritance of blast resistance in nearisogenic lines of rice Phytopathology 82: 746-749.

McCouch SR, Teytelman L, Xu Y, Lobos KB, Clare K, Walton M, Fu B, Maghirang R, Li Z, Xing Y, Zhang Q, Kono I, Yano M, Fjellstrom R, DeClerck G, Schneider D, Cartinhour S, Ware D and Stein L (2002) Development and mapping of 2240 new SSR markers for rice (Oryza sativa L.). DNA Research 9: 199-207.

Nunes CDM, Carvalho FIF, Pierobom CR and Oliveira AC (2007) Genética da resistência de cultivares de arroz à raça IA-1 de Pyricularia grisea. Fitopatologia Brasileira 32: 64-69.

Prabhu AS, Filippi MC, Silva GB, Silva-Lobo VL and Morais OP (2009) An unprecedented outbreak of rice blast on a newly released cultivar BRS Colosso in Brazil. In Wang GL and Valent B (eds.) Advances in genetics, genomics and control of rice blast. Springer Science, Netherlands, p. 257-267.

Sharma TR, Madhav MS, Singh BK, Shanker P, Jana TK, Dala V, Pandit A, Singh A, Gaikwad K, Upreti HC and Singh NK (2005) High-resolution mapping, cloning and molecular characterization of the $\mathrm{Pik}^{\mathrm{h}}$ gene of rice, which confers resistance to Magnaporthe grisea. Molecular Genetics and Genomics 274: 569-578.

Strickberger MW (1971) Genetics. Macmillan, New York, 868p.

Suh JP, Roh JH, Cho YC, Han SS, Kim YG and Jena KK (2009) The Pi40 gene for durable resistance to rice blast and molecular analysis of pi40-advanced backcross breeding lines. Phytopathology 99: 243-250.

Yang Q, Lin F, Wang L and Pan Q (2009) Identification and mapping of Pi41, a major gene conferring resistance to rice blast in the Oryza sativa subsp. indica reference cultivar, 93-11. Theoretical and Applied Genetics 118: 1027-1034.

Yu ZH, Mackill DJ and Monman JM (1986) Inheritance of resistance to blast in some traditional and improved rice cultivars. Phytopathology 77: 323-326.

Zhou E, Jia Y, Singh P, Correll JC and Lee FN (2007) Instability of the Magnaporthe oryzae avirulence gene AVR-Pita alters virulence. Fungal Genetics and Biology 44: 1024-1034. 